\title{
Developing English for Front Office Learning Materials
}

\author{
I Gusti Putu Satria Wibawa ${ }^{1}$ \\ Universitas Pendidikan Ganesha, Indonesia \\ satriawibawa921@gmail.com \\ Nyoman Karina Wedanthi ${ }^{2}$ \\ Universitas Pendidikan Ganesha, Indonesia \\ karina.wedhanti@undiksha.ac.id \\ Kadek Sintya Dewi ${ }^{3}$ \\ Universitas Pendidikan Ganesha, Indonesia \\ sintya09@yahoo.com \\ I Gede Budasi ${ }^{4}$ \\ Universitas Pendidikan Ganesha, Indonesia \\ gede.budasi@undiksha.ac.id
}

\begin{abstract}
This study aims to develop English language materials of front office for second semester students of the eleventh grade at SMK N 2 Singaraja. This study adopts the Design and Development (D\&D) which is guided by data collection through six instruments, namely questionnaires for teacher and front office staff, Google form for teachers and students, checklist for students, and checklist for expert judges. There are three stages that the researcher takes to complete this study, namely designing, developing, and evaluating the quality of the teaching materials (product) so that it can be categorized as a good material. The result is that there are four topics developed by the researcher, namely (1) Renewal of reservations, (2) Cancellation of reservations, (3) Handling of group reservations orally and in writing, and (4) Handling of individual reservations orally and in writing.
\end{abstract}

Keywords: Design and Development, Front Office, Teaching Materials

\section{INTRODUCTION}

As we know, Indonesia is an international tourism destination. That fact makes the tourism sector contributes a lot of income to the Indonesian state. One area that is highly developed tourism area is Bali. Almost all domestic and foreign citizens have visited Bali because of the view and unique culture. This is proven from the Bali Provincial Statistics Center data that recorded 528,883 tourists from foreign countries had come to Bali in January 2020. That number is very impressive for a region that is not too large. Seeing the rapid development of Bali tourism, many tourism schools are located in Bali. It is expected that with the many tourism schools in Bali can create human resources who are able to compete and be creative.

With so many vocational high schools in Bali, the potential for tourism will certainly increase in a promising direction as the dream job of most people. This fact requires vocational high schools to provide appropriate learning through the 
material needed by students including skills, knowledge, and readiness. Of course, these goals can be realized by applying English for a specific purpose (ESP). According to Hutchinson and Waters (1987), ESP is learning English for specific needs. The language learning that is needed must use appropriate and material must be structured. The needs in the world of tourism are very important for the hospitality industry in Bali especially for the qualified front office staff. The quality of front office staff needs further improvement for the sake of the continuity of the world of tourism which is full of professionalism demands at work.

Front office is a department whose employees are crucial in the hospitality industry. According to Bousri (2018), the front office is in charge of receiving guests for the first time at the hotel. Guests who come to the hotel want to get services and instructions that make it easy for them. This is the big role the front office plays as the first person to serve guests. It is hoped that the front office staff will master various information about the hotel and have good quality in speaking English which is important to serve foreign guests. Being a front office staff is a big responsibility. Judging from the many demands as front office staff, it is important for tourism schools to apply the right material for students who have an interest in tourism. Therefore, students who have an interest in working as a front office must get relevant learning material.

Based on preliminary observations made by researchers, several tourism schools have not been maximized in providing appropriate front office subject matter for their students. One of the researchers' attentions was SMK N 2 Singaraja in class $\mathrm{XI}$. It was found that the front office lessons were given only based on sources from the internet without proper textbooks. Litz (2005) states that proper textbooks have a significant effect on increasing student potential during language learning and are indeed very helpful for teachers in obtaining many references in teaching. This fact was obtained after researchers gave questionnaires in the form of Google forms to teachers and students. Many criteria must be known to students who want to become front office staff. Based on this problem, the researcher plans to make authentic learning materials needed by students in studying the hospitality industry especially in the front office field. Relevant teaching material really needs to be developed to support front office lessons in second semester of eleventh grade at SMK N 2 Singaraja.

The gap from this research is the lack of student motivation in learning because students are bored with the material provided. The teacher only gives a little bit explanation without examples of dialogue. A variety of material is needed to make the learning process for the front office material to be more enjoyable. It is hoped by having specific and interesting materials can make students more enthusiastic in learning. The material must contain the required elements as well as clear illustrations. Karakas \& Karaca (2015) states that teaching using visual illustrations is able to stimulate students' language skills so that the learning process runs effectively and is not boring. Therefore, the right teaching material can increase student motivation in learning especially regarding front office lessons.

Based on the problems found, the researcher composed a front office English textbook for eleventh grade students in the second semester at SMK N 2 Singaraja based on the needs analysis. In addition, Pushpanathan (2013) states that needs analysis can open up insights and improve the perspective of teachers 
and students in innovating on a material. Need analysis can assist researchers in evaluating existing deficiencies and finding solutions. The book designed in this study focused on improving four skills such as reading, listening, writing and speaking. In line with the initial objectives, this book was expected to improve student achievement, especially in the front office field. The quality of the abilities of students interested in the front office must be supported by books that were relevant in the learning process. Therefore, it is important for researchers to analyze student needs according to material with special objectives or what is often referred to as ESP.

ESP is English which has a specific purpose. That purpose is what makes it special because it differs from one field to another. According to Hutchinson \& Waters (1992), ESP is useful for classifying English in various different fields such as business, tourism, law, and medical. ESP is also a forum for language teaching approaches by referring to the material students need. According to Trisyanti (2009), ESP is studied by adults who have special and professional goals. In other words, ESP will be very effective if it is in accordance with students' interests related to their goals. It can be said that ESP learning cannot be done in general. ESP teaching must go through certain procedures in order to be specific. Therefore, it is important to know why ESP is compulsory to be studied.

The application of ESP must be supported by a need analysis. Needs analysis is an important component in the development of learning materials, especially about ESP. Iwai, et al (1999) stated that needs analysis is the basis for information gathering activities that will meet the needs of various groups of students in learning. Data from needs analysis will determine the gap of the material developed. In other words, needs analysis can improve a material designed for a particular purpose. According to Tomlinson (1998), the material development is an effort to improve language teaching materials carried out by teachers, researchers, and lecturers related to learning material that has been designed. The material can be developed through books, videos and others. According to Cunningsworth (1995), the material developed must support a number of conditions such as being a forum for presentations, sources of student training activities, reference sources, and guidelines for inexperienced teachers.

The similar study was done by Budasi, et al (2015) entitled "Developing English Materials for Front Office Course for the Students of Hotel Accommodation of PPLP Dhyana Pura". The aim of this study is to develop appropriate English language material for the front office course and examine how relevant English language material is taught to front office course students at PPLP Dhyana Pura. The design of this research is R\&D, which is identifying problems and needs analysis phases. The results found are that there are 11 materials that have been developed specifically for the front office course. Therefore, this finding is very influential on ESP material intended for courses such as the front office.

\section{METHOD}

Design

In this study, researchers used design and development method. Richey and Klein (2017) states that the D\&D method is a systematic study method that 
includes design, development, and evaluation as an empirical basis for making or perfecting a product. According to Puffer (2010), there are several steps in the application of the D\&D method. The data collection process can be seen in Figure 1.

Figure 1 Procedures D\&D from Puffer

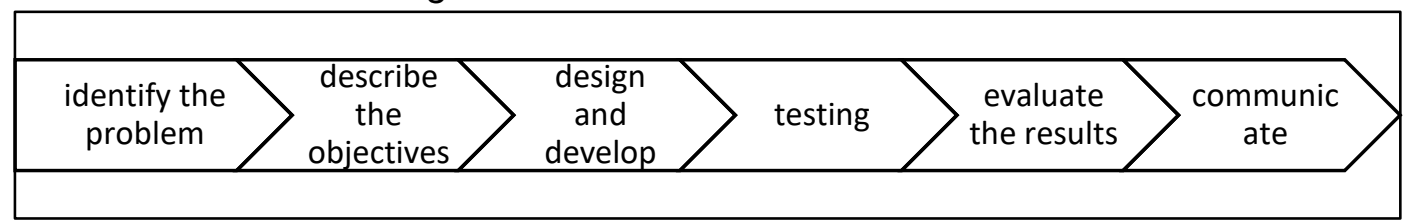

Based on some of the steps listed above, the researcher only uses three processes, namely design, development, and evaluation due to time constraints and products that reach the evaluation stage.

\section{Setting and Participants}

The subjects of this study were an English teacher who was teaching in hotel accommodation class especially Front office subject of SMK N 2 Singaraja, students in class XI AP1 as known as hotel accommodation class, and staff hotel who worked in Front Office department. The subjects of this study were chosen because they have experience in the front office field.

\section{Instruments and Data Analysis}

In the data collection process, researchers used six instruments, namely questionnaires for teacher and front office staff, Google form for teachers and students, checklist for students, and checklist for expert judges. The questionnaire and checklist were adapted from Basturkmen (2010), Litz (2005), Hutchinson and Waters (2008). Qualitative descriptive techniques are used by researchers in structured data analysis. Sugiani (2014) states that qualitative descriptive techniques are able to identify or process data as a whole in the form of a systematic explanation. This technique allows researchers to process data and collaborate with the results of a review of qualitative data from various aspects such as responses, input, and suggestions from questionnaires which will have an effect on improving the quality of the product being developed.

\section{FINDINGS \& DISCUSSIONS} found:

The following are three results based on the data analysis the researcher

\section{Developing materials based on student's need analysis}

1. The Result of Syllabus Analysis

The materials that will be developed are renewal of reservations, cancellation of reservations, handling of group reservations orally and in writing, and handling of individual reservations orally and in writing.

2. The Result of observation form 
Based on the results of the questionnaire via Google Form, researchers can see that most students have an interest in books that have lots of pictures or illustrations because they are judged to be more varied in terms of content.

3. The Result of Student's Checklist

The results of the questionnaire need analysis were accumulated from 40 students of class XI AP1. Then the results of the questionnaire for front office staff and teachers did not add to the language function. To determine the percentage of questionnaire results can be formulated as follows:

Number of students who answered "need" $\quad$ X 100\%

Total number of students

Table 1. The Result of Student's Checklist

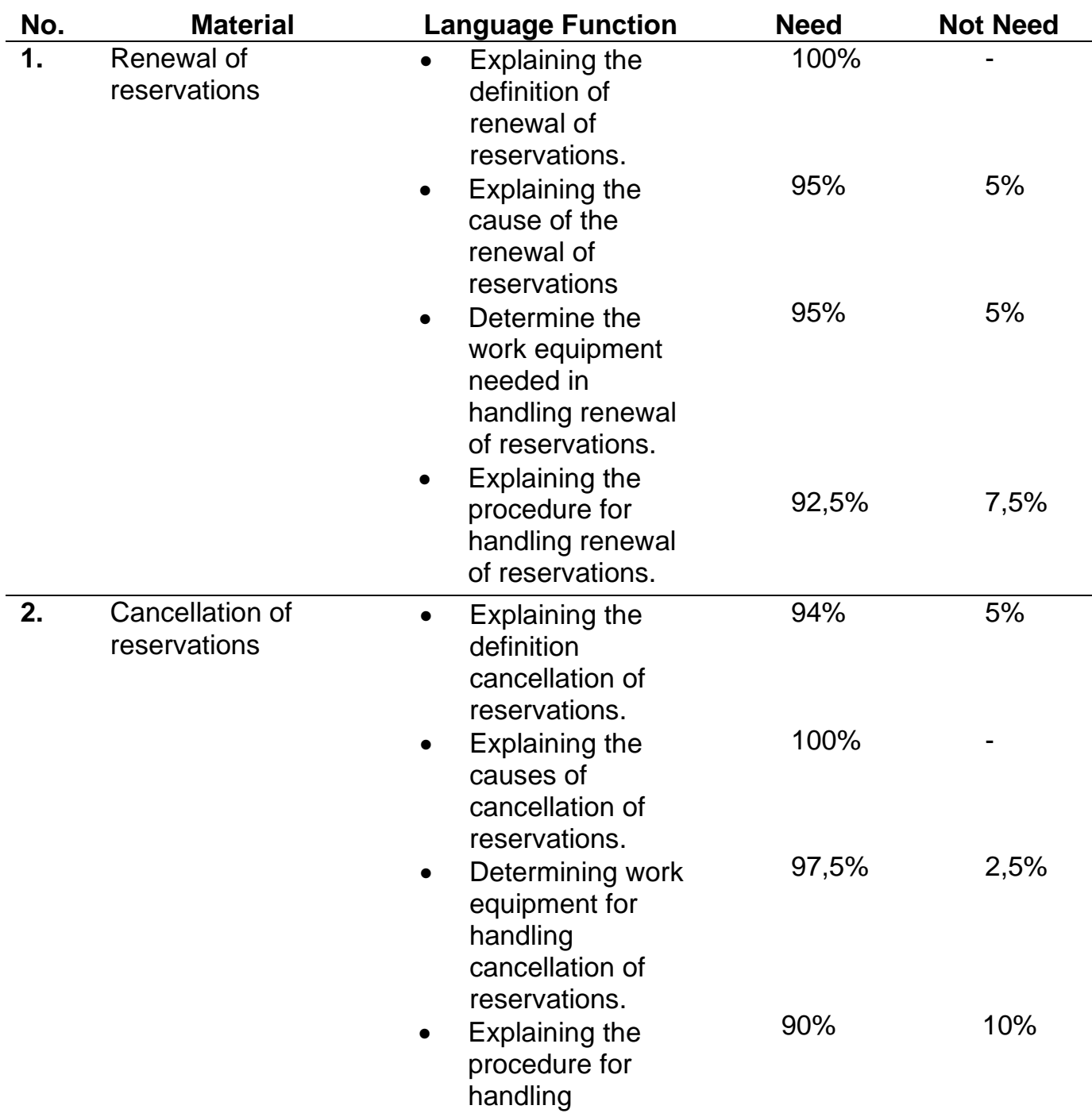


The Art of Teaching English as a Foreign Language, Vol.2 No.1 2021

p-ISSN : 2656-8942, e-ISSN : 2684-8546

DOI: $10.36663 /$ tatefl.v2i1.103

\begin{tabular}{|c|c|c|c|c|c|}
\hline & & & $\begin{array}{l}\text { cancellation of } \\
\text { reservations }\end{array}$ & & \\
\hline 3. & $\begin{array}{l}\text { Handling of group } \\
\text { reservations orally } \\
\text { and in writing }\end{array}$ & $\bullet$ & $\begin{array}{l}\text { Explaining the } \\
\text { scope of handling } \\
\text { of group } \\
\text { reservations orally } \\
\text { and in writing } \\
\text { Determining work } \\
\text { equipment for } \\
\text { handling of group } \\
\text { reservations orally } \\
\text { and in writing } \\
\text { Explaining } \\
\text { procedure in } \\
\text { handling of group } \\
\text { reservations orally } \\
\text { and in writing }\end{array}$ & $92,5 \%$ & $7,5 \%$ \\
\hline 4 & $\begin{array}{l}\text { Handling of individual } \\
\text { reservations orally } \\
\text { and in writing }\end{array}$ & - & $\begin{array}{l}\text { Explain the scope } \\
\text { of handling of } \\
\text { individual } \\
\text { reservations orally } \\
\text { and in writing } \\
\text { Determining work } \\
\text { equipment for } \\
\text { handling of } \\
\text { individual } \\
\text { reservations orally } \\
\text { and in writing } \\
\text { Explaining } \\
\text { procedure in } \\
\text { handling of } \\
\text { individual } \\
\text { reservations orally } \\
\text { and in writing. }\end{array}$ & $100 \%$ & $10 \%$ \\
\hline
\end{tabular}

Average

$95,5 \% \quad 4,5 \%$

The result of students' responses above showed that most of students agree with the statements of the checklist with the average obtained for the agreed response was $95,5 \%$ and $4,5 \%$ for disagreed response. The results of the syllabus (document analysis), questionnaires as well as the needs analysis checklist were obtained by the researcher that the basic framework that is indispensable in the product to be developed is as follows: (1) English materials specifically for the front office for the eleventh grade of the second semester must contain several topics in accordance with the syllabus. (2) The material developed must contain a variety of adequate explanations that are presented in the form of input, content focus, and vocabulary focus. (3) Material must provide language expression or language function. It is presented in a language focus which aims to make students know how language works. The language focus is also equipped 
with vocabulary and pronunciation methods that will make it easier for students to practice them. (4) The material that will be contained in the book (product) must have an important element that trains the four basic skills in English which consist of listening, speaking, reading and writing. (5) The material must authentic and increase the level of creativity, motivation, and language skills of students which are accommodated by the number of individual or group assignments.

Authentic material certainly needs to be developed in an interesting and intuitive way in learning certain things, especially about the front office. This is useful so that students studying front office materials can be more motivated to enter the world of work in the future. This study is supported by study conducted by Kilickaya (2004) entitled "Authentic materials and cultural content in EFL classrooms". This study aims to find out how the work (advantages and disadvantages) of authentic material in EFL classrooms and to relate it to the influence of cultural content in the existing syllabus. The results of the study stated that authentic material allowed students to get to know the real language and the content being studied more easily. So, authentic material becomes a forum for students to learn content that will be useful in real life.

\section{The Design of English Materials for Front Office Department}

In the design stage of teaching materials (products) which consisted of four units, the researcher made a blueprint based on the teaching materials used by the teacher, a needs analysis questionnaire, and an analysis syllabus. The product made by the researcher refers to the theory of Hutchinson \& Waters (1987) which contains the use of four main skills in a book consisting of input, content focus, language focus, and tasks.

Basically, this developed teaching material is intended to provide a more varied and interesting presentation of material so that students can explore the world of the front office more easily. Design and development is a form of research based on Richey \& Klein's theory (2017). One study that uses the D\&D model and supported this study is conducted by Sahrir, et al (2012) entitled "Employing Design and Development Research (DDR) Approaches in the Design and Development of Online Arabic Vocabulary Learning Games Prototype". The study was conducted to describe the Arabic vocabulary learning game developed on a web supported by the DDR approach for students at the International Islamic University of Malaysia (IIUM). This study focuses on developing interactive and attractive online-based learning media. Feedback from students will be collected and evaluated after application in accordance with the principles of D\&D.

\section{The Quality of the Product English Material for Front Office}

A good product design must pass an expert judge's assessment in a relevant way. The results of the expert judge review can be seen in table 2 below. 
The Art of Teaching English as a Foreign Language, Vol.2 No.1 2021

p-ISSN : 2656-8942, e-ISSN : 2684-8546

DOI: $10.36663 /$ tatefl.v2i1.103

Table 2. The Result of Checklist for Expert Judges

\begin{tabular}{|c|c|c|c|c|c|c|}
\hline \multirow[t]{2}{*}{ No. } & \multirow[t]{2}{*}{ Dimension } & \multirow[t]{2}{*}{ Quality of product } & \multirow{2}{*}{$\begin{array}{c}\text { Relev } \\
\text { ant }\end{array}$} & \multirow{2}{*}{$\begin{array}{l}\text { Irrele } \\
\text { vant }\end{array}$} & \multicolumn{2}{|c|}{ Score (1-5) } \\
\hline & & & & & $\begin{array}{c}\text { Judge } \\
1\end{array}$ & Judge 2 \\
\hline \multirow[t]{6}{*}{1.} & $\begin{array}{l}\text { Layout and } \\
\text { Design }\end{array}$ & $\begin{array}{l}\text { The textbook includes a } \\
\text { detailed overview of the } \\
\text { function, structures and } \\
\text { vocabulary that will be } \\
\text { taught in each unit (Litz, } \\
\text { 2005). }\end{array}$ & $\sqrt{ }$ & & 5 & 5 \\
\hline & & $\begin{array}{l}\text { The layout and design } \\
\text { are appropriate and } \\
\text { clear (Litz, 2005). }\end{array}$ & $\sqrt{ }$ & & 5 & 5 \\
\hline & & $\begin{array}{l}\text { The textbook is } \\
\text { organized effectively } \\
\text { (Litz, 2005). }\end{array}$ & $\sqrt{ }$ & & 5 & 5 \\
\hline & & $\begin{array}{l}\text { The textbook provides a } \\
\text { vocabulary list } \\
\text { (Litz, 2005). }\end{array}$ & $\sqrt{ }$ & & 5 & 5 \\
\hline & & $\begin{array}{l}\text { The textbook provides } \\
\text { review section } \\
\text { (Litz, 2005). }\end{array}$ & $\sqrt{ }$ & & 4 & 5 \\
\hline & & $\begin{array}{l}\text { The textbook provides } \\
\text { clear objectives } \\
\text { (Litz, 2005). }\end{array}$ & $\sqrt{ }$ & & 4 & 5 \\
\hline \multirow[t]{5}{*}{2.} & Activities & $\begin{array}{l}\text { The textbook provides a } \\
\text { balance of activities } \\
\text { (Litz, 2005). }\end{array}$ & $\sqrt{ }$ & & 4 & 5 \\
\hline & & $\begin{array}{l}\text { The activities } \\
\text { encourage sufficient } \\
\text { communicative and } \\
\text { meaningful practice } \\
\text { (Litz, 2005). }\end{array}$ & $\sqrt{ }$ & & 5 & 4 \\
\hline & & $\begin{array}{l}\text { The activities } \\
\text { incorporate an } \\
\text { individual, pairs and } \\
\text { group work } \\
\text { (Litz, 2005). }\end{array}$ & $\sqrt{ }$ & & 4 & 5 \\
\hline & & $\begin{array}{l}\text { The grammar points } \\
\text { and vocabulary items } \\
\text { are introduced in } \\
\text { motivating and realistic } \\
\text { contexts (Litz, 2005). }\end{array}$ & $\sqrt{ }$ & & 5 & 5 \\
\hline & & $\begin{array}{l}\text { The activities promote } \\
\text { creative, original and } \\
\text { independent responses } \\
\text { (Litz, 2005). }\end{array}$ & $\sqrt{ }$ & & 5 & 4 \\
\hline 3. & Skills & $\begin{array}{l}\text { The materials include } \\
\text { and focus on the skills }\end{array}$ & $\sqrt{ }$ & & 5 & 5 \\
\hline
\end{tabular}


The Art of Teaching English as a Foreign Language, Vol.2 No.1 2021

p-ISSN : 2656-8942, e-ISSN : 2684-8546

DOI: $10.36663 /$ tatefl.v2i1.103

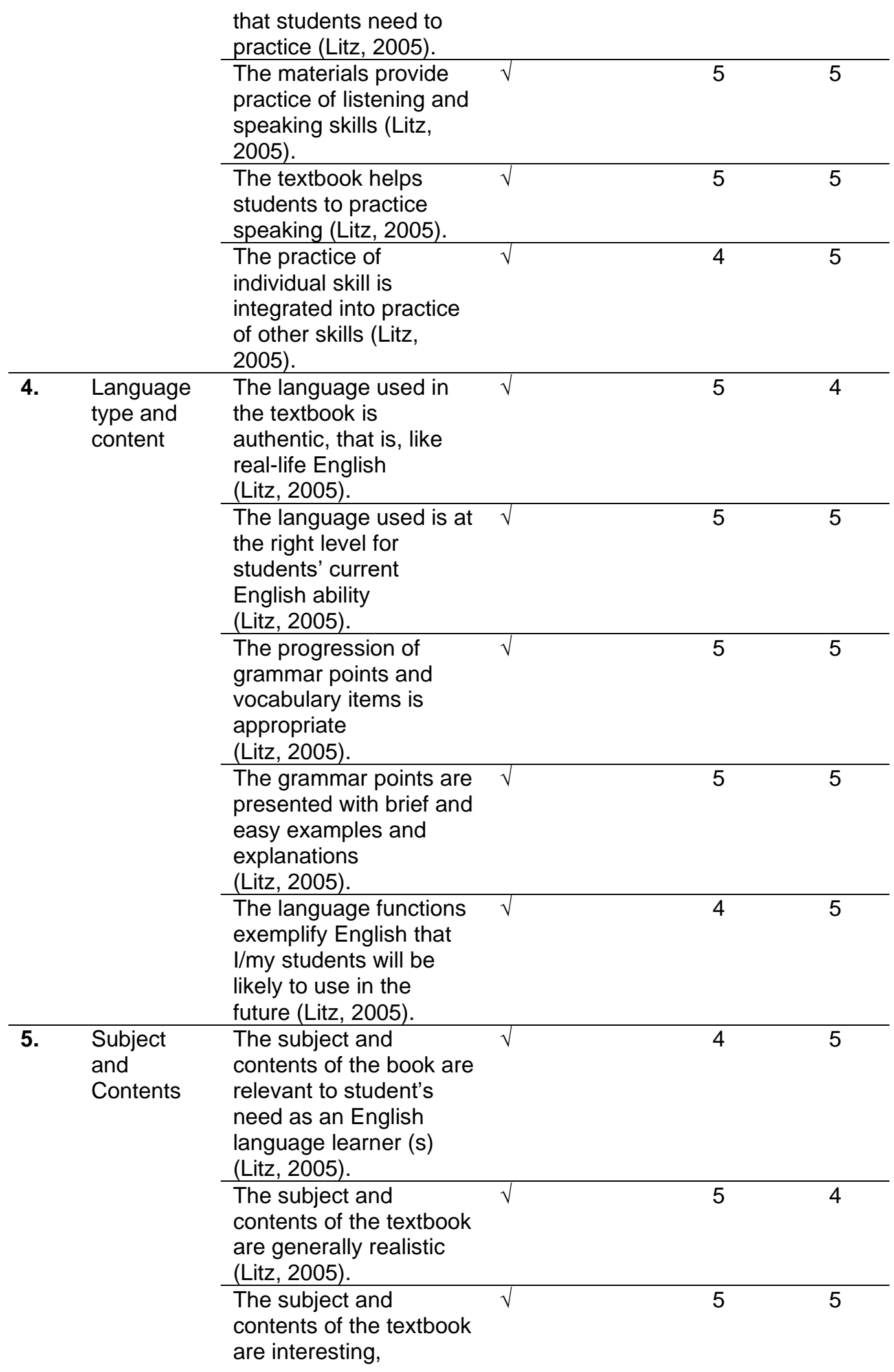




$\begin{aligned} & \text { challenging and } \\ & \text { motivating } \\ & \text { (Litz, 2005). }\end{aligned}$
$\begin{aligned} & \text { There are sufficient } \\ & \text { varieties in the subject } \\ & \text { and contents of the } \\ & \text { textbook (Litz, 2005). }\end{aligned}$
$\begin{aligned} & \text { The materials are not } \\ & \text { culturally biased and } \\ & \text { they do not portray any } \\ & \text { negative stereotypes } \\ & \text { (Litz, 2005). }\end{aligned}$

The two expert judges involved in assessing the product draft are lecturers of English Language Education at Ganesha University of Education. The first expert judges gave a score of 118 while the second expert judges gave a total score of 121. Based on the results of the expert judge's assessment, it states that Gregory's result is "1" which means the product has a high level of validity. It can be seen from the the results of the formula that the percentage of product validity in the aspects of learning media that has been designed is obtained $94.4 \%$ and $96.8 \%$. This percentage is categorized as very good when converted to a scale of 5 . By obtaining this percentage, we can be sure that the product developed only needs a little touch (revision) from the expert judges and media experts.

Most of the results of the data analysis stated that the teaching material (product) was categorized as very good because it was in accordance with a more complete analysis of material needs for front office students. This excellent category is influenced by the abundance of interesting and interactive content in teaching materials such as illustrations, examples of dialogue, and assignments that hone the four basic skills in spoken and non-spoken English. One similar study was conducted by Sadiku (2015) entitled "The Importance of Four Skills Reading, Speaking, Writing, listening in a Lesson Hour" which aims to understand how important it is to use the four basic skills during one hour of lessons which refers to the many benefits resulting from. Of course, honing the four basic skills refers more to the student centre because students are more able to explore, express, and innovate but are still under teacher guidance.

\section{CONCLUSION}

Based on the results of the research, there are four units developed, namely renewal of reservations, cancellation of reservations, handling of group reservations orally and in writing, and handling of individual reservations orally and in writing. Each unit that has been developed consists of a unit cover, input, content focus, language focus, and assignments that can train the four basic skills in English (Listening, Speaking, Reading, and Writing) especially for front office materials. The use of questionnaires and checklists helps researchers analyze the syllabus by involving teachers and students as research subjects. Researchers began to outline the material based on the needs analysis. The expert judge is 
also involved in evaluating the material design that has been developed based on the theory of Litz (2005) regarding the criteria for good ESP teaching materials. The scores obtained from the two expert judges were $94.4 \%$ and $96.8 \%$, which are categorized as very good.

\section{REFERENCES}

Bousri, N. (2018). The Development of English Conversation Training Course for Front Office Staff: A Case Study of Baiyok Hotel, Bangkok, Thailand. Social Sciences, 7(1), 22. https://doi.org/10.11648/j.ss.20180701.14

Hutchinson, T., \& Waters, A. (1987). English for Specific Purposes: A learningcentered approach. Cambridge: Cambridge University Press.

Iwai, T., Kondo, K., Lim, D. S. J., Ray, G. E., Shimizu, H., \& Brown, J. D. (1999). Japanese language needs analysis 1989-1999. Second Language Teaching \& Curriculum Center, c, 1-87. http://hdl.handle.net/10125/8950

Karakaş, A., \& Karaca, G. (2015). USE AND IMPORTANCE OF ILLUSTRATION AS Yabancı Dil Öğretiminde Resmin Materyal Olarak Kullanımı ve Önemi. January 2011, 351-358.

Kilickaya, F. (2004). Authentic materials and cultural content in EFL classrooms. The Internet TESL Journal, 10(7).

Litz, D. R. A. (2005). Textbook Evaluation and Elt Management: a South Korean Case Study. Asian EFL Journal, 48(1), 8.

Pushpanathan, Ln. T. (2013). A Need For Needs Analysis. International Journal of Applied Research International Journal of Applied Research \& Studies ISSN, II(December 2012), 2278-9480.

Sadiku, L. M. (2015). The Importance of Four Skills Reading, Speaking, Writing, Listening in a Lesson Hour. European Journal of Language and Literature, 1(1), 29. https://doi.org/10.26417/ejls.v1i1.p29-31

Sahrir, M. S., Alias, N. A., Ismail, Z., \& Osman, N. (2012). Employing design and development research (DDR) approaches in the design and development of online arabic vocabulary learning games prototype. Turkish Online Journal of Educational Technology, 11(2), 108-119.

Trisyanti, U. (2009). Developing Materials for Esp (English for Specific Purposes) Class. Jurnal Sosial Humaniora, 2(1), 66-77. https://doi.org/10.12962/j24433527.v2i1.666 